\title{
Success Factor Analysis of Multiple Project Management
}

\author{
Taftazani Hakim ${ }^{1}$, Ervina Ahyudanari ${ }^{2}$, and Rita Ambarwati ${ }^{3}$ \\ ${ }^{1}$ Department of Management Technology, Institut Teknologi Sepuluh Nopember, Surabaya \\ ${ }^{2}$ Department of Civil Engineering, Institut Teknologi Sepuluh Nopember, Surabaya \\ ${ }^{3}$ Department of Management, Universitas Muhammadiyah Sidoarjo, Sidoarjo \\ e-mail: taftazanihakim@gmail.com
}

\begin{abstract}
PT XYZ is one of the largest manufacturing industry companies in Indonesia, that using multiple project management. Several concurrent projects existed, or also referred as multiple project management. Multiple project often cause several problems, such as the long duration of the project because of wrong determining priorities and limited resources. These problems certainly affect the success of the project in general. The success of the project is measured by the project iron triangle, that is budget, quality and time. Success of a project is important, and many research has been done to determine the project success factors. However, there is still limited research related to multiple projects. This is exploratory research, and initial stage where researchers will determine the factors that support the success of multiple projects. Following the variable identification from literature study, a survey was conducted. This research use exploratory factor analysis (EFA) and mean vs standard deviation analysis. Results of the study, success factors of multiple projects formed six factors including communication, organizational, technical, external, resource, and project factors. As a recommendation for the company, which factors are significant are seen from the results of the mean analysis, with the highest significance results are : (1) Material availability; (2) Realistic planning; and (3) Manager's competence.
\end{abstract}

Keywords—Factor Analysis, EFA, Multiple Projects.

\section{INTRODUCTION}

$\mathrm{C}$ OMPANIES today are often found in conditions where operational changes often occur. Many of these companies lost in the competition because of the reality conditions that occurred outside the company. Technology that continues to grow and global competition is one of the causes. To improve management and efficiency, many companies now use multiple project management [1]. Working in multiple- project conditions can be a challenge [2].

Managing multiple projects, generally done in two ways. The first is self-management, namely projects carried out by internal companies. The second one is contractor method, where the company uses a lot of vendors or contractors for several projects. As one of the largest companies in Indonesia, PT XYZ which is engaged in the manufacturing industry, has also adopted multiple projects to run its business. Adopts a self-management method, in which multiple projects are managed internally by the company, there is several division in the company. One of the divisions in this company called Electronics and Electrical Service Division which is the division responsible for the project the operation and maintenance of the company's electricity. This division is divided into several department. For electricity in the primary that handle tobacco processing environment, there are 2 department namely Primary Operation and Primary Development. Electricity in the Secondary environment or cigarette maker-packer machine, there are also 2 department namely Secondary Operation and Secondary Project. In addition there are 2 other department, namely Electronic Supporting in charge of handling electrical projects that are not directly related to production machines, and Electrical in charge of handling general electricity projects, providing Medium Voltage to Low Voltage electricity supply.

Electronic Supporting is one of the department in the electronic and electrical services division which is devoted to electricity projects that are not directly related to production machinery. Projects that are not directly related to production such as compressor installation, chiller installation, Air Handling Unit (AHU) installation, Deepwell installation, telephone installation, CCTV, telepresence and Waste Water Treatment installation. The project, which is a request from another internal department or division. There is Project Management system that functions is to monitor every incoming request. Incoming request or called SRM Incoming, in a period of 1 month, SRM Incoming amount can be more than 20 requests. Just in 2018, a total of 238 projects were received, of which $54 \%$ of projects were successfully completed on time / before due date, $37 \%$ exceeded due date, and $9 \%$ until 2019 were still not carried out. The definition of project success is varies. Project success can be considered in two aspects, namely project success and project management success. According to Nethate et al., project success is measured by the overall objectives of the project, and project management success is measured in the traditional way of cost, time and quality performance [3].

As a multi-project actor, the problem faced is that the project is getting longer, and there are delays. This is a common problem faced by companies that carry out multiple projects. However, research that addresses multiple projects is still limited. Previous studies discuss changes in organizational design/company structure in managing multiple projects, how to manage multiple projects using demand-based approach methods, motivation under multiple project conditions and what factors influence the success of multiple project groups [2], [4]-[6]. Inspired by previous research, which states that multiple- projects management different when compared to single- projects management. Some challenges or problems in doing multiple projects are often displayed in the literature. For example, simultaneous allocation of resources between projects, organizational 
The $1^{\text {st }}$ International Conference on Business and Engineering Management (IConBEM)

February $1^{\text {st }} 2020$, Institut Teknologi Sepuluh Nopember, Surabaya, Indonesia

structure and control, communication, lack of commitment, and unclear tasks and responsibilities [3].

Based on the background as described above, this research intends to identify what factors influence/support the success of multiple projects and find out which factors are significant and not significant to the success of multiple projects management.

\section{METHOD}

Technical analysis of data in quantitative research using statistics. There are two kinds of statistics used for data analysis in research, namely descriptive statistics and inferential statistics. Inferential statistics include parametric statistics and nonparametric statistics [7]. The use of parametric and nonparametric statistics depends on the assumptions and types of data to be analyzed. Parametric statistics require many assumptions to be met. The main assumption is that the data to be analyzed must be normally distributed. Furthermore, the use of one of the tests requires that the data of two or more groups tested be homogeneous, in the regression the linearity assumption must be met [7].

In this study, the main survey results were analyzed using different methods according to the research objectives. Part 1 questions (respondent respondent background) in the main survey were analyzed using diagrams. This diagram is simple to evaluate using each percentage. Section 2 (factors affecting the success of multiple projects) was analyzed using various methods, such as validity and reliability analysis, mean analysis and factor analysis.

Data collected must be checked to test the quality of the questionnaire before conducting data analysis. Research requires valid and reliable data. Validity is a measure that shows that the measured variable is really the variable that the researcher wants to study [8]. Validity is a measure that shows the validity of an instrument. An instrument is said to be valid if it is able to measure what is desired and can reveal data from the variables studied appropriately. To determine the level of validity of this instrument, the study used a Pearson product moment statistical test. The questionnaire was declared valid if it was obtained $r$ count $>r$ table or $p$ value $<0.05$.

Reliability is a measure that shows that the measuring instrument used in behavioral research has reliability as a measuring tool, including measuring through the consistency of measurement results from time to time if the phenomenon measured does not change [8]. Reliability testing is carried out to measure the extent to which the measurement results are relatively consistent if the measurements are repeated twice or more. Many methods are used in research, but what is often used is the Cronbach Alpha method. A variable is said to be reliable if the Cronbach Alpha value $>0.60$.

Data analysis techniques used by the authors in this study used the analysis of the mean and standard deviation. The greater the mean value, the variable significantly influences the success of the project. When analyzing data obtained from a questionnaire survey using the mean, there are several factors that have identical scores, and to differentiate those factors in terms of ranking, Standard Deviation (SD) is also calculated. Standard deviation is a measure used to measure the amount of variation or spread of data value groups. Standard deviations close to 0 indicate that data points tend to be very close to the statistical mean (also called the expected value) of the set, while high standard deviations indicate that data points are scattered over great distances.

The data analysis technique used by the authors in this study is factor analysis. According to Wibisono, that factor analysis is used to ensure that the question items in the questionnaire can represent well the variables investigated [9]. This method simplifies complex and diverse relationships among a set of observed research variables. According to Wijaya, that factor analysis is used to identify a number of relatively small factors that can be used to explain a large number of interconnected variables [10].

In factor analysis, the following assumptions must be met, as follows [11]:

a. Correlation between Independent variables. The amount of correlation or correlation between independent variables must be strong enough, for example above 0.5 .

b. Partial Correlation. Large partial correlation, the correlation between two variables by assuming the other variables are fixed, it must be small. In SPSS detection of partial correlation is given via the Anti- Image Correlation option.

c. Testing the entire correlation matrix (correlation between variables), measured by the magnitude of the Bartlett Test of Sphericity or Measuring Sampling Adequacy (MSA). This test requires a significant correlation between at least several variables.

According to Wijaya, the basic process of factor analysis includes the following matters [10]:

a. Determine what variables or factors to be analyzed.

b. Test the variables that have been determined by the method of Bartlett's test of sphericity and measurement of MSA (Measure of Sampling Adequacy). At this stage a number of variables are filtered to obtain variables that meet the requirements for analysis. To see whether there is a correlation, it can be seen in the Kaiset Meyer Oikin (KMO) Measure of Sampling Adequancy test, which is an index used to examine the accuracy of factor analysis. A high value between $0.5-1.0$ means that factor analysis is correct, if less than 0.5 factor analysis is said to be incorrect.

c. The factoring process is extracted from a set of variables, so that one or more factors are formed. From this process a Communalities Table will emerge, which basically shows the number of factors/variances (can be in percentages) of a variable that can initially be explained by existing factors. The extreme value of communalities is between 0.0 (the variable does not correlate with other variables) to 1.0 (the variance of the variable is perfectly caused by a number of shared factors). The next table that appears is the Total Variance Explained Table, which displays the eigen values of each factor. The greater the eigen value of each factor, the more reliable the factor is to represent a group of variables.

$\mathrm{d}$. The rotation process is carried out to reduce some ambiguous factors. The simplest rotation is orthogonal rotation where the axis is maintained at $90^{\circ}$. The factor rotation method used is Varimax whose results can be done in 1 literacy. The varimax method of many variables can have high loading or near height on the same factor. 
The $1^{\text {st }}$ International Conference on Business and Engineering Management (IConBEM)

February $1^{\text {st }} 2020$, Institut Teknologi Sepuluh Nopember, Surabaya, Indonesia

Table 1.

Validity, Reliability and Normality Test Result

\begin{tabular}{cccc}
\hline $\begin{array}{c}\text { Variable } \\
\text { Code }\end{array}$ & $\begin{array}{c}\text { Validity } \\
\text { P-Value }\end{array}$ & $\begin{array}{c}\text { Reliability } \\
\text { Cronbach's Alpha }\end{array}$ & Normality K-S \\
\hline X1.1 & 0,000 & 0,908 & 0,000 \\
X1.2 & 0,000 & 0,907 & 0,000 \\
X1.3 & 0,000 & 0,910 & 0,000 \\
X2.1 & 0,000 & 0,909 & 0,000 \\
X2.2 & 0,000 & 0,902 & 0,000 \\
X3.1 & 0,000 & 0,902 & 0,000 \\
X3.2 & 0,000 & 0,903 & 0,000 \\
X4.1 & 0,000 & 0,903 & 0,000 \\
X4.2 & 0,000 & 0,903 & 0,000 \\
X4.3 & 0,000 & 0,901 & 0,000 \\
X5.1 & 0,000 & 0,905 & 0,000 \\
X5.2 & 0,000 & 0,904 & 0,000 \\
X5.3 & 0,000 & 0,900 & 0,000 \\
X6.1 & 0,000 & 0,898 & 0,000 \\
X6.2 & 0,000 & 0,899 & 0,000 \\
X7.1 & 0,000 & 0,904 & 0,000 \\
X7.2 & 0,000 & 0,902 & 0,000 \\
X7.3 & 0,000 & 0,904 & 0,000 \\
X8.1 & 0,000 & 0,899 & 0,000 \\
X8.2 & 0,000 & 0,902 & 0,000 \\
X8.3 & 0,000 & 0,903 & 0,000 \\
X9.1 & 0,000 & 0,900 & 0,000 \\
X9.2 & 0,000 & 0,901 & \\
X9.3 & 0,000 & 0,902 & \\
\hline \hline & & & 000 \\
\hline
\end{tabular}

e. Interpretation of the factors that have been formed, specifically giving names to the factors that have been formed that are considered to represent these variables.

\section{RESULTS AND DISCUSSION}

Data validity was tested using Pearson product moment, and data reliability test was performed using Cronbach's Alpha . P values was less than 0.05 ( $\mathrm{P}$ value $<0.05)$ and Cronbach's Alpha values was greater than 0.6 for all variables. So it can be concluded that the data for this study is valid and realiable. Which further analysis can be continued. The table of $\mathrm{P}$ values and Cronbach's Alpha score for the factors that influence the success of multiple projects is listed in Table 1.

After the validity and reliability tests, the data normality test is done using Kormogorov-Smirnov. With a value of 0 or $<0.05$ for all variables, it can be concluded that the data for this study are not normally distributed for all variables. The Kormogorov-Smirnov score table for factors affecting the success of multiple projects is also listed in Table 1.

To get a ranking of the factors that influence the success of multiple projects at PT XYZ Tbk, an analysis of the mean and standard deviation was performed. After analyzing the mean and standard deviation, it is obtained the ranking of variables according to the order of the most significant influence on the success of multiple projects in PT XYZ Tbk to less significant ones. The table of the mean and standard deviations for the factors that affect the success of multiple projects is listed in Table 2.

To classify the factors that influence the success of multiple projects, a factor analysis is performed. The type of factor analysis in this research is exploratory factor analysis,
Table 2.

Mean and Standart Deviation Result

\begin{tabular}{clcc}
\hline Rank & \multicolumn{1}{c}{ Variable } & Mean & SD \\
\hline 1 & Material availability (X7,1) & 4,720 & 0,533 \\
2 & Realistic planning (X3,2) & 4,590 & 0,588 \\
3 & Manager competence (X8,2) & 4,570 & 0,573 \\
4 & Availability of operational tools (X7,3) & 4,560 & 0,656 \\
5 & Support top management (X4,1) & 4,540 & 0,593 \\
6 & Cooperative (X9,3) & 4,530 & 0,674 \\
7 & Job description (X4,3) & 4,510 & 0,595 \\
8 & Client competency (X8,3) & 4,500 & 0,732 \\
9 & Business Process (X4,2) & 4,460 & 0,688 \\
10 & Suitability of design (X2,2) & 4,460 & 0,717 \\
11 & Worker competence (X8,1) & 4,440 & 0,656 \\
12 & Reliability of subcontractors (X5,3) & 4,440 & 0,656 \\
13 & Availability of human resources (X7,2) & 4,320 & 0,750 \\
14 & Project monitoring (X9,1) & 4,290 & 0,715 \\
15 & Project meeting (X9,2) & 4,280 & 0,766 \\
16 & Tender method (X3,1) & 4,280 & 0,792 \\
17 & Risk identification (X6,1) & 4,220 & 0,773 \\
18 & Risk allocation (X6.2) & 4,170 & 0,726 \\
19 & Design changes (X2,1) & 4,160 & 0,884 \\
20 & Project Uniqueness (X1,3) & 4,150 & 0,999 \\
21 & Project Urgency (X1,2) & 4,100 & 0,927 \\
22 & Project Size (X1,1) & 4,090 & 0,986 \\
23 & Government policy (X5,2) & 3,810 & 0,918 \\
24 & Economic stability (X5,1) & 1,105 \\
\hline & & \\
\hline
\end{tabular}

which is a factor analysis technique in which several factors will be formed in the form of latent variables that cannot be determined before the analysis is carried out. The condition for factor analysis is that the data must be normally distributed as tested in the previous sub-chapter. Before the factor analysis is carried out, the assumption test is carried out first. If there is an assumption test that is not met then the factor analysis process is repeated by eliminating the variables that the assumption test does not meet. The process will be repeated until all variables pass the assumption test.

The first assumption of factor analysis is Bartlett test of sphericity. The results of the calculation generated the value of Bartlett test of spehricity of 380.371 with a significance of 0,000 . Thus Bartlett test of spehricity meets the requirements because the significance is below 0.05 (5\%). Assumptions Analysis The second factor is the meyer meyer olkin measure of sampling (KMO), which is the index of the distance comparison between the correlation coefficient and the partial correlation coefficient. If the sum of the squares of partial correlation coefficients among all pairs of variables is small compared to the sum of the squares of the correlation coefficient, it will produce a KMO value close to 1 . The KMO value is considered sufficient if more than 0.5 . The results showed that the kaiser meyer olkin measure of sampling was 0.853 . Thus the KMO requirements meet the requirements because they have values above 0.5. Bartleet and KMO test results for inhibiting factors for the adoption of the first round of BIM are listed in table 3.

Furthermore, it is seen the value of measures of sampling adequacy (MSA) in the anti image correlation matrix with a "a" sign on the SPSS output. If the MSA value of a variable is greater $0.5(\mathrm{MSA}>0.5)$ then the variable meets the MSA requirements, whereas if the MSA value of a variable is 
The $1^{\text {st }}$ International Conference on Business and Engineering Management (IConBEM)

February $1^{\text {st }} 2020$, Institut Teknologi Sepuluh Nopember, Surabaya, Indonesia

Table 5.

Rotated Component Matrix

\begin{tabular}{|c|c|c|c|c|c|c|}
\hline Code & 1 & 2 & 3 & 4 & 5 & 6 \\
\hline X9,1 & ,768 & & & & & \\
\hline$X 4,2$ & ,767 & & & & & \\
\hline X9,2 & ,762 & & & & & \\
\hline $\mathrm{X} 9,3$ & ,734 & & & & & \\
\hline X6,1 &, 525 & & & & & \\
\hline X8,1 & ,510 & & & & & \\
\hline $\mathrm{X} 3,2$ & & ,801 & & & & \\
\hline $\mathrm{X} 4,1$ & & ,759 & & & & \\
\hline X6.2 & & 602 & & & & \\
\hline$X 8,2$ & & ,591 & & & & \\
\hline X5,3 & &, 562 & & & & \\
\hline$X 8,3$ & &, 515 & & & & \\
\hline $\mathrm{X} 4,3$ & & ,441 & & & & \\
\hline $\mathrm{X} 2,1$ & & & ,762 & & & \\
\hline $\mathrm{X} 3,1$ & & & 695 & & & \\
\hline $\mathrm{X} 1,1$ & & &, 560 & & & \\
\hline $\mathrm{X} 2,2$ & & & ,441 & & & \\
\hline $\mathrm{X} 5,2$ & & & & ,882 & & \\
\hline X5,1 & & & & ,882 & & \\
\hline $\mathrm{X} 7,3$ & & & & &, 721 & \\
\hline$X 7,2$ & & & & & 650 & \\
\hline X7,1 & & & & & ,530 & \\
\hline $\mathrm{X} 1,3$ & & & & & & ,758 \\
\hline $\mathrm{X} 1,2$ & & & & & &, 722 \\
\hline
\end{tabular}

smaller $0.5(\mathrm{MSA}<0.5)$ than the variable does not meet the MSA requirements. So the factor analysis process must be repeated without including variables that do not meet the MSA requirements.

The next step after the MSA values for all variables have met the requirements then proceed with looking at the value of communality. Each variable must meet the communality requirements which is greater than 0.5 (communality $>0.5$ ). If there is a variable with an Extraction value in the Communalities table $<0.5$, then the variable does not meet the communality requirements and must be excluded from testing and the analysis process must be repeated again by not including variables that do not meet the communality requirements. The repetition is the same as the repetition of the MSA conditions described above. The results of the MSA scores and the results of the value of communality for the factors that influence the success of multiple projects are listed in Table 4.

From Table 4 it is known that the value of communality meets the requirements for all variables, next is determining the number of new factors formed by looking at the eigenvalue. The results of SPSS eigenvalue output can be seen in Figure 1. The number of factors formed are those that have eigenvalues above 1. At this stage there are 6 new formed factors formed. The initial variable grouping of new formation factors is by looking at the rotated component matrix table. Table 5 shows the value of the Rotated Component Matrix for the factors that influence the success of multiple projects.

The naming of the new formation factors is the result of factor analysis. By looking at the interrelationships between variables collected in a new factor, the name that is most suitable for the new factor is determined. Factor 1 is named the communication factor. In previous studies about the factors of project success many included communication factors [6], [12]. Although according to Patanakul and Milosevic, communication factors are included in the category of organizational culture, together with commitment, teamwork, and performance rewards [6]. The issue of communication is considered important in a multiple project management, where the project manager leads several projects running simultaneously and the individual projects also carry out several projects at the same time.

Other research showed that at least $71.6 \%$ of project managers and $78.7 \%$ of contractors considered matters of communication to be 'very important' [12]. Shows that the majority of respondents in their research consider communication as a key success factor in managing construction projects. Project managers and contractors agree that the handover procedure is the most important item that forms communication. This points to the adoption of a more client-oriented approach to construction projects. Regarding the handover procedure, see the construction industry as increasingly becoming a service industry [13]. This means that industry players must become more client- oriented, with the emphasis shifting from "working for clients" to "working with clients." Other books shows that project managers must communicate, on a regular basis, with the project team, stakeholders legitimate interests, clients and, if applicable, project sponsors [14].

Indicators of the success of multiple projects in the communication factor, in this study are project monitoring, project meetings, cooperatives, business processes, employee competencies, and risk identification. For the first three indicators, in chapter 2, it has been explained how this indicator refers to the communication factor. The business process, which was originally an "organizational factor", with the item statement of the ease of the project workflow and the design validation process was finally classified in communication, because both statements were actually supported by good communication.

Factor 2 is named organizational factor, which consists of realistic planning, top management support, risk allocation, manager competency, sub-contractor reliability, client competency, and job description. Of all the indicators, only the reliability of subcontractors is deemed inappropriate in organizational factors. For this reason, research needs to be done using the CFA method to further confirm the formation of the classification of factors that influence the success of the project in this study.

Factor 3 is named technical factor. Consists of design changes, contractor selection method, project size, and design suitability. The size of the project is seen from a technical perspective, no longer by the project factors. Is the project technically large in location, design, and technical difficulties faced by the project implementer.

Factor 4 is named external factor. Included in this factor include economic stability and government policy. Both indicators are clearly beyond the ability of project management. Or outside the environment and the project manager's ability to be predictable and planned.

Factor 5 is named the resource factor. Included in this factor include material resources, work tools and project workers. The classification of these factor groups is consistent with previous theories and studies [1], [3], [12], [15], [16]. 
The $1^{\text {st }}$ International Conference on Business and Engineering Management (IConBEM)

February $1^{\text {st }} 2020$, Institut Teknologi Sepuluh Nopember, Surabaya, Indonesia

Factor 6 is named the project factor. Included in this factor include the urgency of the project and the uniqueness of the project. The size of the project, in this study included in the classification of technical factors as explained above. The urgency and uniqueness of this project is in accordance with previous studies,

Based on table 2, overall the respondents ranked first, the most significant factor influencing the success of multiple projects is the resource factor (material availability). The availability of material is considered very important in supporting the success of multiple projects in this study. This must be supported by the supply chain process which must be continuously improved by the company.

The second ranking of the factors that most significantly influences the success of multiple projects is the organizational factor (realistic planning). Projects that come on an ongoing basis, need to do realistic scheduling so that project implementers can coordinate well.

The third ranking of the factors that most significantly influences the success of multiple projects is the communication factor (manager competency). These results are consistent with research conducted by Nethathe. Which implies that, when running many projects, functional managers play an important role in the organization[3]. These managerial competencies need to be the focus of the company, to always develop manager's competencies by conducting various kinds of training and skills improvement, both soft skills and hard skills.

\section{CONCLUSION}

The conclusions of this study in stating there are 6 factors formed that affect the success of multiple projects, namely: communication, organization, technical, external, resources, and projects. Three most significant factor, for the recommendations that can be given to companies are that the company continues to innovate in the supply chain to support the availability of materials during the project, carry out the development and project planning stages in a

\section{ACKNOWLEDGEMENT}

The authors appreciate PT XYZ and co-worker who were involved in survey in this research at year 2019.

\section{REFERENCES}

[1] P. Patanakul and D. Milosevic, "A competency model for effectiveness in managing multiple projects," J. High Technol. Manag. Res., vol. 18, no. 2, pp. 118-131, 2008, doi: 10.1016/j.hitech.2007.12.006.

[2] P. Patanakul, J. K. Pinto, and M. B. Pinto, "Motivation to perform in a multiple-project environment: The impact of autonomy, support, goal clarity, and opportunities for learning," J. Eng. Technol. Manag., vol. 39, pp. 65-80, 2016, doi: 10.1016/j.jengtecman.2016.02.001.

[3] J. M. Nethathe, C. C. Van Waveren, and K.-Y. Chan, "Extended critical success factor model for management of multiple projects: An empirical view from Transnet in South Africa," South African J. Ind. Eng., vol. 22, no. 2, pp. 189-203, 2011.

[4] M. Aubry and M. Lavoie-Tremblay, "Rethinking organizationa design for managing multiple projects," Int. J. Proj. Manag., vol. 36, no. 1, pp. 12-26, 2018, doi: 10.1016/j.ijproman.2017.05.012.

[5] D. Bumblauskas, S. Rosol, and P. Bumblauskas, "Managing multiple projects: Applying a demand-based approach," Int. J. Manag. Educ., vol. 16, no. 1, pp. 52-62, 2018, doi: 10.1016/j.ijme.2017.11.004

[6] P. Patanakul and D. Milosevic, "The effectiveness in managing a group of multiple projects: Factors of influence and measurement criteria," Int. J. Proj. Manag., vol. 27, no. 3, pp. 216-233, 2009, doi: 10.1016/j.ijproman.2008.03.001

[7] D. Sugiyono, Metode Penelitian Bisnis. Bandung: Pusat Bahasa Depdiknas, 2008.

[8] Z. Zulganef, "The existence of overall satisfaction in service customer relationships," Gadjah Mada Int. J. Bus., vol. 8, no. 3, pp. 301-321, 2006, doi: 10.22146/gamaijb.5614

[9] D. Wibisono, Riset Bisnis Panduan bagi Praktisi \& Akademisi. Jakarta, Indonesia: Gramedia Pustaka Utama, 2003.

[10] T. Wijaya, Analisis Multivariat. Yogyakarta, Indonesia: Universitas Atma Jaya, 2010.

[11] S. Santoso, Menggunakan SPSS Untuk Statistik Non Parametrik. Jakarta, Indonesia: Elex Media Komputindo, 2006.

[12] H. Garbharran, J. Govender, and T. Msani, "Critical success factors influencing project success in the construction industry," Acta Structilia, vol. 19, no. 2, pp. 90-108, 2013.

[13] S. Kärnä, J. M. Junnonen, and V. M. Sorvala, "Modelling structure of customer satisfaction with construction," J. Facil. Manag., vol. 7, no. 2, pp. 111-127, 2009, doi: 10.1108/14725960910952505.

[14] R. Newton, The Project Manager: Mastering The Art of Delivery. Harlow, England: Pearson Education, 2012.

[15] O. P. Sanchez, M. A. Terlizzi, and H. R. de O. C. de Moraes, "Cost and time project management success factors for information systems development projects," Int. J. Proj. Manag., vol. 35, no. 8, pp. 1608-1626, 2017, doi: 10.1016/j.ijproman.2017.09.007.

[16] R. Maqbool, "Efficiency and effectiveness of factors affecting renewable energy projects; an empirical perspective," Energy, vol. 158, pp. 944-956, 2018, doi: 10.1016/j.energy.2018.06.015. 